\title{
CRITICISM AND THE HISTORY OF ART
}

\begin{abstract}
$A$ RTISTIC and literary criticism is often looked upon by 1 artists as a morose and tyrannical pedagogue who gives capricious orders, imposes prohibitions, and grants permissions, thus aiding or injuring their works by wilfully deciding upon their fate. And so the artists either shew themselves submissive, humble, flattering, adulatory, toward it, while hating it in their hearts; or, when they do not obtain what they want, or their loftiness of soul forbids that they should descend to those arts of the courtier, they revolt against it, proclaiming its uselessness, with imprecations and mockery, comparing (the remembrance is personal) the critic to an ass that enters the potter's shop and breaks in pieces with quadrupedante ungule sonitu the delicate products of his art set out to dry in the sun. This time, to tell the truth, it is the artists' fault, for they do not know what criticism is, expecting from it favours which it is not in a position to grant, and injuries which it is not in a position to inflict: since it is clear that since no critic can make an artist of one who is not an artist, so no critic can ever undo, overthrow, or even slightly injure an artist who is really an artist, owing to the metaphysical impossibility of such an act: these things have never happened in the course of history, they do not happen in our day, and we can be sure that they will never happen in the future. But sometimes it is the critics themselves, or the self-styled critics, who do actually present themselves as pedagogues, as oracles, as guides of art, as legislators, seers, and prophets; they command artists to


do this or that, they assign themes to them and declare that certain subjects are poetical, and certain others not; they are discontented with the art at present produced, and would prefer one similar to that prevailing at this or that epoch of the past, or at another of which they declare they catch a glimpse in the near or remote future; they will reprove Tasso for not being Ariosto, Leopardi for not being Metastasio, Manzoni for not being Alfieri, D'Annunzio because he is not Berchet or Fra Jacopone; and they describe the great artist of the future, supplying him with ethic, philosophy, history, language, metric, with architectonic and colouristic processes, and with whatever it may seem to them that he stands in need. And this time it is clear that the blame lies with the critic; and the artists are right in behaving toward such brutality in the way that we behave toward beasts, which we try to tame, to illude and to delude, in order that they may serve us; or we drive them away and send them to the slaughter-house when they are no longer good for any service. But for the honour of criticism we must add that those capricious critics are not so much critics as artists : artists who have failed and who aspire to a certain form of art, which they are unable to attain, either because their aspiration was contradictory, or because their power was not sufficient and failed them; and thus, preserving in their soul the bitterness of the unrealised ideal, they can speak of nothing else, lamenting everywhere its absence, and everywhere invoking its presence. And sometimes, too, they are artists who are anything but failures,-indeed, most felicitous artists, - but, owing to the very energy of their artistic individuality, incapable of emerging from themselves in order to understand forms of art different from their own, and disposed to reject them with violence; they are aided in this negation by the odium figulinum, the jealousy 
of the artist for the artist, which is without doubt a defect, but one with which too many excellent artists appear to be stained for us to refuse to it some indulgence similar to that accorded to the defects of women, so difficult, as we know, to separate from their good qualities. Other artists should calmly reply to these artist-critics: "Continue doing in your art what you do so well, and let us do what we can do"; and to the artists who have failed and improvised themselves critics: "Do not claim that we should do what you have failed in doing, or what is work of the future, of which neither you nor we know anything." As a fact, this is not the usual reply, because passion forms half of it; but this is indeed the logical reply, which logically terminates the question, though we must foresee that the altercation will not terminate, but will indeed last as long as there are intolerant artists and failures - that is to say, for ever.

And there is another conception of criticism, which is expressed in the magistrate and in the judge, as the foregoing is expressed in the pedagogue or in the tyrant; it attributes to criticism the duty, not of promoting and guiding the life of art, - which is promoted and guided, if you like to call it so, only by history; that is, by the complex movement of the spirit in its historical course,-but simply to separate, in the art which has already been produced, the beautiful from the ugly, and to approve the beautiful and reprove the ugly with the solemnity of a properly austere and conscientious sentence. But I fear that the blame of uselessness will not be removed from criticism, even with this other definition, although perhaps the motive of this blame may to some extent be changed. Is there really need of criticism in order to distinguish the beautiful from the ugly? The production itself of art is never anything but this distinguishing, because the artist arrives at purity of expression precisely by elimi- 


\section{Criticism and the History of Art}

nating the ugly which menaces to invade it; and this ugliness is his tumultuous human passions striving against the pure passion of art: his weaknesses, his prejudices, his convenience, his laissez faire, his haste, his having one eye on art and another on the spectator, on the editor, on the impresario-all of them things that impede the artist in the physiological bearing and normal birth of his image-expression, the poet of the verse that rings and creates, the painter of sure drawing and harmonious colour, the composer of melody, and introduces into their work, if care be not taken to defend themselves against it, sonorous and empty verses, incorrections, lack of harmony, discordances. And since the artist, at the moment of producing, is a very severe judge of himself from whom nothing escapes, - not even that which escapes others, -others also discern, immediately and very clearly, in the spontaneity of contemplation, where the artist has been an artist and where he has been a man, a poor man; in what works, or in what parts of works, lyrical enthusiasm and creative fancy reign supreme, and in what they have become chilled and have yielded their place to other things, which pretend to be art, and therefore (considered from the aspect of this pretence) are called "ugly." What is the use of the sentence of criticism, when the sentence has already been given by genius and by taste? Genius and taste are legion, they are people, they are general and secular consensus of opinion. So true is this, that the sentences of criticism are always given too late; they consecrate forms that have already been solemnly consecrated with universal applause (pure applause must not, however, be confounded with the clapping of hands and with social notoriety, the constancy of glory with the caducity of fortune), they condemn ugliness already condemned, grown wearisome and forgotten, or still praised in words, but with a bad conscience, 


\section{The Breviary of Esthetic}

through prejudice and obstinate pride. Criticism, conceived as a magistrate, kills the dead or blows air upon the face of the living, who is quite lively, in the belief that its breath is that of the God who brings life; that is, it performs a useless task, because this has previously been performed. I ask myself what critics have established the greatness of Dante, of Shakespeare, or of Michelangelo: if, among the legions who have acclaimed and do acclaim these great men, there are or have been men of letters and professional critics, their acclamation does not differ in this case from that of youth and of the people, who are all equally ready to open their hearts to the beautiful, which speaks to all, save sometimes, when it is silent, on discovering the surly countenance of a critic-judge.

And so there arises a third conception of criticism: the criticism of interpretation or comment, which makes itself small before works of art and limits itself to the duty of dusting, placing in a good light, furnishing information as to the period at which a picture was painted and what it represents, explaining linguistic forms, historical allusions, the presumptions of fact and of idea in a poem; and in both cases, its duty performed, permits the art to act spontaneously within the soul of the onlooker and of the reader, who will then judge of it according as his intimate taste tells him to judge. In this case the critic appears as a cultivated cicerone or as a patient and discreet schoolmaster: "Criticism is the art of teaching to read," is the definition of a famous critic; and the definition has not been without its echo. Now no one contests the utility of guides to museums or exhibitions, or of teachers of reading, still less of erudite guides and masters who know so many things hidden from the majority and are able to throw so much light on subjects. Not only has the art that is most remote from us need of 
this assistance, but also that of the nearest past, called contemporary, which, although it treats of subjects and presents forms that seem to be obvious, is yet not always sufficiently obvious; and sometimes a great effort is requisite in order to prepare people to feel the beauty of a little poem or of some work of art, though born but yesterday. Prejudices, habits and forgetfulness form hedges barring the approach to that work: the expert hand of the interpreter and of the commentator is required to remove them. Criticism in this sense is certainly most useful, but we do not see why it should be called criticism when that sort of work already possesses its own name of interpretation, comment, or exegesis. To call this criticism is at best useless, for it is equivocal.

It is equivocal because criticism demands to be, wishes to be and is something different: it does not wish to invade art, nor to rediscover the beauty of the beautiful, or the ugliness of the ugly, nor to make itself small before art, but rather to make itself great before art which is great and, in a certain sense, above it. What, then, is legitimate and true criticism?

First of all, it is at once all three of the things that I have hitherto explained; that is to say, all these three things are its necessary conditions, without which it would not arise. Without the moment of art (and, as we have seen, that criticism which affirms itself to be productive or an aid to production, or as repressing certain forms of production to the advantage of certain other forms, is, in a certain sense, art against art), the experience of art would be wanting to the critic, art created within his spirit, severed from nonart, and enjoyed in preference to that. And finally, this experience would be wanting without exegesis, without the removal of the obstacles to reproductive fancy, which supply the spirit with those presumptions of historical knowledge 
298 The Breviary of Esthetic

of which it has need, and which are the wood to burn in the fire of fancy.

But here, before going further, it will be well to resolve a grave doubt which has been agitated and is still agitated, both in philosophical literature and in ordinary thought, and which certainly, where justified, would not only compromise the possibility of criticism, of which I am discoursing, but also of reproductive fancy itself, or taste. Is it truly possible to collect, as does exegesis, the materials required for reproducing the work of art of others (or our own past work of art, when we search our memory and consult our papers in order to remember what we were when we produced it), and to reproduce that work of art in our fancy in its genuine features? Can the collection of the material required be ever complete? And however complete it be, will the fancy ever permit itself to be chained by it in its labour of reproduction? Will it not act as a new fancy, introducing new material? Will it not be obliged to do so, owing to its impotence truly to reproduce the other and the past? Is the reproduction of the individual, of the individuum ineffabile, conceivable, when every sane philosophy teaches that the universal alone is eternally reproducible? Will not the reproduction of the works of art of others or of the past be consequently a simple impossibility; and will not what is usually alleged as an undisputed fact in ordinary conversation, and is the expressed or implied presupposition in every dispute upon art, be perhaps (as was said of history in general) une fable convenue?

Truly, when we consider the problem rather from without, it will seem most improbable that the firm belief which all possess in the comprehension and intelligence of art is without foundation, - all the more, if we observe that these very people who deny the possibility of reproductions in 


\section{Criticism and the History of Art}

abstract theory-or, as they call it, the absoluteness of taste - are yet most tenacious in maintaining their own judgments of taste, and very clearly realise the difference there is between the affirmation that wine pleases or displeases me because it agrees or disagrees with my physiological organism, and the affirmation that a poem is beautiful, and another a pastiche: the second order of judgments (as Kant shows in a classical analysis) carries with it the uncoercible pretension to universal validity; souls become passionate about it; and in days of chivalry there were even those who maintained the beauty of the "Gerusalemme," sword in hand, whereas no one that we know has ever been killed maintaining, sword in hand, that wine was pleasant or unpleasant. To object that works artistically base have yet pleased many or someone, and if not others, their author, is not valid, because their having pleased is not set in doubt (since nothing can be born in the soul without the consent of the soul, and consequently without a correlative pleasure); but it is doubted whether that pleasure were asthetic, and were founded upon a judgment of taste and beauty. And passing from extrinsic scepticism to intrinsic consideration, it should be said that the objection to the conceivability of the æsthetic reproduction is founded upon a reality conceived in its turn as a shock of atoms, or as abstractly monadistic, composed of monads without communication among themselves and harmonised only from without. But that is not reality : reality is spiritual unity, and in spiritual unity nothing is lost, everything is an eternal possession. Not only the reproduction of art, but, in general, the memory of any fact (which is indeed always reproduction of intuitions), would be inconceivable without the unity of the real; and if we had not been ourselves Cæsar and Pompey, - that is, that universal which was once determined as Cæsar and Pompey and is 
now determined as ourselves, they living in us, - we should be unable to form any idea of Cæsar and Pompey. And further, the doctrine that individuality is irreproducible and the universal only reproducible is certainly a doctrine of "sound" philosophy, but of sound scholastic philosophy, which separated universal and individual, making the latter an accident of the former (dust carried along by time), and did not know that the true universal is the universal individuated, and that the only true effable is the so-called ineffable, the concrete and individual. And finally, what does it matter if we have not always ready the material for reproducing with full exactitude all works of art or any work of art of the past? Fully exact reproduction is, like every human work, an ideal which is realised in infinity, and therefore is always realised in such a manner that it is admitted at every instant of time by the conformation of reality. Is there a suggestion in a poem of which the full signification escapes us? No one will wish to affirm that that suggestion, of which we now have a crepuscular vision that fails to satisfy, will not be better determined in the future by means of research and meditation and by the formation of favourable conditions and sympathetic currents.

Therefore, inasmuch as taste is most sure of the legitimacy of its discussions, by just so much is historical research and interpretation indefatigable in restoring and preserving and widening the knowledge of the past; not mentioning that relativists and sceptics, both in taste and in history, utter their desperate cries from time to time, which do not reduce anyone, not even themselves, as we have seen, to the effectual desperation of not judging.

Closing here this long but indispensable parenthesis and taking up the thread of the discourse, art, historical exegesis, and taste, if they be conditions of criticism, are not yet criti- 
cism. Indeed, nothing is obtained by means of that triple presupposition, save the reproduction and enjoyment of the image-expression; that is to say, we return and place ourselves neither more nor less than in the place of the artist-producer in the act of producing his image. Nor can we escape from those conditions, as some boast of doing, by proposing to ourselves to reproduce in a new form the work of the poet and the artist by providing its equivalent; hence they define the critic: artifex additus artifici. Because that reproduction in a new garment would be a translation, or a variation, another work of art, to some extent inspired by the first; and if it were the same, it would be a reproduction pure and simple, a material reproduction, with the same words, the same colours, and the same tones-that is, useless. The critic is not artifex additus artifici, but philosophus additus artifici: his work is not achieved, save when the image received is both preserved and surpassed; it belongs to thought, which we have seen surpass and illumine fancy with new light, make the intuition perception, qualify reality, and therefore distinguish reality from unreality. In this perception, this distinction, which is always and altogether criticism or judgment, the criticism of art, of which we are now especially treating, originates with the question: whether and in what measure the fact, which we have before us as a problem, is intuition-that is to say, is real as such; and whether and in what measure, it is not such-that is to say, is unreal: reality and unreality, which in art are called beauty and ugliness, as in logic they are called truth and error, in economy gain and loss, in ethic good and evil. Thus the whole criticism of art can be reduced to this briefest proposition, which further serves to differentiate its work from that of art and taste (which, considered in themselves, are logically mute), and from exegetical erudition (which lacks logi- 
cal synthesis, and is therefore also logically mute): "There is a work of art $a$," with the corresponding negative: "There is not a work of art $a . "$

It seems to be a trifle, for the definition of art as intuition seemed to be neither more nor less than a trifle, but it has on the contrary been since seen how many things it included in itself, how many affirmations and how many negations: so many that, although $I$ have proceeded and proceed in a condensed manner, I have not been able and will not be able to afford more than brief mention of them. That proposition or judgment of the criticism of art, "The work of art $a$ is," implies, above all, like every judgment, a subject (the intuition of the work of art $a$ ) to conquer which is needed the labour of exegesis and of fantastic reproduction, together with the discernment of taste: we have already seen how difficult and complicated this is, and how many go astray in it, through lack of fancy, or owing to slightness and superficiality of culture. And it further implies, like every judgment, a predicate, a category, and in this case the category of art, which must be conceived in the judgment, and which therefore becomes the concept of art. And we have also seen, as regards the concept of art, to what difficulties and complications it gives rise, and how it is a possession always unstable, continually attacked and ambushed, and continually to be defended against assaults and ambushes. Criticism of art, therefore, develops and grows, declines and reappears, with the development, the decadence, and the reappearance of the philosophy of art; and each can compare what it was in the Middle Ages (when it may almost be said that it was not) with what it became in the first half of the nineteenth century with Herder, with Hegel, and with the Romantics, in Italy with De Sanctis; and in a narrower field, what it was with De Sanctis, and what it became in the 
following period of naturalism, in which the concept of art became clouded and finally confused with physic and with physiology, and even with pathology. And if disagreements as to judgments depend for one half, or less than half, upon lack of clearness as to what the artist has done, lack of sympathy and taste for another half, or more than half, this arises from the small clearness of ideas upon art; whence it often happens that two individuals are substantially at one as to the value of a work of art, save that the one approves what the other blames, because each refers to a different definition of art.

And owing to this dependence of criticism upon the concept of art, as many forms of false criticism are to be distinguished as there are false philosophies of art; and, limiting ourselves to the principal forms of which we have already discoursed, there is a kind of criticism which, instead of reproducing and characterising art, breaks in pieces and classifies it; there is another, moralistic, which treats works of art like actions in respect of ends which the artist proposes or should have proposed to himself; there is hedonistic criticism, which presents art as having attained or failed to attain to pleasure and amusement; there is also the intellectualistic form, which measures progress according to the progress of philosophy, knows the philosophy but not the passion of Dante, judges Ariosto feeble because he has a feeble philosophy, Tasso more serious because his philosophy is more serious, Leopardi contradictory in his pessimism. There is that criticism usually called psychological, which separates content from form, and instead of attending to works of art, attends to the psychology of the artists as men; and there is the other form, which separates form from content and is pleased with abstract forms because, according to cases and to individual sympathies, they recall 


\section{The Breviary of Esthetic}

antiquity or the Middle Ages; and there is yet another, which finds beauty where it finds rhetorical ornaments; and finally there is that which, having fixed the laws of the kinds and of the arts, receives or rejects works of art according as they approach or retreat from the models which they have formed. I have not enumerated them all, nor had I the intention of so doing, nor do $I$ wish to expound the criticism of criticism, which could be nothing but a repetition of the already traced criticism and dialectic of Esthetic; and already here and there will have been observed the beginnings of inevitable repetition. It would be more profitable to summarise (if even a rapid summary did not demand too much space) the history of criticism, to place the historical names in the ideal positions that I have indicated, and to shew how criticism of models raged above all during the Italian and French classical periods, conceptualistic criticism in German philosophy of the nineteenth century, that of moralistic description at the period of religious reform or of the Italian national revival, psychology in France with Sainte-Beuve and many others; how the hedonistic form had its widest diffusion among people in society, among boudoir and journalistic critics; that of classifications, in schools, where the duty of criticism is believed to have been successfully fulfilled when the so-called origin of metres and literary and artistic kinds and their representatives has been investigated.

But the forms which I have briefly described are forms of criticism, however erroneous; though this cannot, in truth, be said of other forms which raise their banners and combat among themselves, under the names of "æsthetic criticism" and "historical criticism." These I beg leave to baptise, on the contrary, as they deserve, pseudo-esthetic criticism (or æsthetistic), and pseudo-historical criticism (or historisti- 


\section{Criticism and the History of Art}

cal). These two forms, though very much opposed, have a common hatred of philosophy in general, and of the concept of art in particular: against any intervention of thought in the criticism of art, which in the opinion of the former is the affair of artistic souls; in the opinion of the latter, of the erudite. In other words, they debase criticism below criticism, the former limiting it to pure taste and enjoyment of art, the latter to pure exegetical research or preparation of materials for reproduction by the fancy. What Æsthetic, which implies thought and concept of art, can have to do with pure taste without concept is difficult to say; and what history can have to do with disconnected erudition relative to art, which is not organisable as history because without a concept of art and ignorant of what art is (whereas history demands always that we should know that of which we narrate the history), is yet more difficult to establish; at the most we could note the reasons for the strange "fortune" which those two words have experienced. But there would be no harm in those names or in the refusal to exercise criticism, provided that the upholders of both should remain within the boundaries assigned by themselves, these enjoying works of art, those collecting material for exegesis; and they might leave criticism to him who should wish to criticise, or satisfy themselves with speaking ill of it without touching problems which properly belong to criticism. In order to attain to such an attitude of reserve it would be necessary neither more nor less than that the æsthetes should never open their mouths in ecstasy about art, that they should silently degustate their joys, and, at the most, that when they met their like they should understand one another, as animals are said to do (who knows, though, if it be true!) without speaking: their countenance unconsciously bearing an expression of ravishment, their arms outstretched in an attitude of 


\section{The Breviary of Esthetic}

wonder, or their hands joined in a prayer of thanksgiving for the joy experienced, should suffice for everything. Historians, for their part, might certainly speak: speak of codices, of corrections, of chronical and of topical dates, of political facts, of biographical occurrences, of sources of works, of language, of syntaxes, of metres, but never of art, which they serve, but to whose countenance, as simple erudites, they cannot raise their eyes, as the maid-servant does not raise them to look upon her mistress, whose clothes she nevertheless brushes and whose food she prepares: sic vos, non vobis. But go and ask of men such abstentions, sacrifices, and heroisms, however extravagant in their ideas and fanatic in their extravagances! In particular, go and ask those who, for one or another reason, are occupied with art all their lives, not to talk of or to judge art ! But the mute æsthetisticians talk of, judge, and argue about art, and the inconclusive historicians do the same; and since in thus talking they are without the guide of philosophy and of the concept of art, which they despise and abhor, and yet have need of a concept, - when good sense does not fortunately happen to suggest the right one to them, without their being aware of it,-they wander among all the various preconceptions, moralistic and hedonistic, intellectualistic and contentistic, formalistic and rhetorical, physiological and academical, which I have recorded, now relying upon this one, now upon that, now confounding them all and contaminating one with the other. And the most curious spectacle (though to be foreseen by the philosopher) is that the æsthetisticians and historicians, those irreconcilable adversaries, although they start from opposite points, yet agree so well that they end by uttering the same fatuities; and nothing is more amusing than to meet again the most musty intellectualistic and moralistic ideas in the pages of deeply moved lovers of 


\section{Criticism and the History of Art}

art (so deeply moved as to hate thought), and in the most positive historians (so positive as to fear compromising their positivity by attempting to understand the object of their researches, which chances this time to be called art).

True criticism of art is certainly esthetic criticism, but not because it disdains philosophy, like pseudo-æsthetic, but because it acts as philosophy and as conception of art; it is historical criticism, not because, like pseudo-history, it deals with the extrinsic of art, but because, after having availed itself of historical data for fantastic reproduction (and till then it is not yet history), when fantastic reproduction has been obtained, it becomes history, by determining what is that fact which has been reproduced in the fancy, and so characterising the fact by means of the concept, and establishing what exactly is the fact that has occurred. Thus, the two things at variance in spheres inferior to criticism coincide in criticism; and "historical criticism of art" and "asthetic criticism" are the same: it is indifferent which word we use, for each may have its special use solely for reasons of convenience, as when, for instance, it is desired to call special attention, with the first, to the necessity of the understanding of art; with the second, to the historical objectivity of its consideration. Thus the problem discussed by certain methodologists is solved, namely, whether history enter into the criticism of art as means or as end: since it is henceforth clear that history adopted as a means is not history, precisely because it is a means, but is exegetic material; and that which enters it as end is certainly history, though it does not enter it as a particular element, but as its constituent whole: which precisely describes the word "end."

But if criticism of art be historical criticism, it follows that it will not be possible to limit the duty of discerning the beautiful and the ugly to simple approval and refusal in 


\section{$308 \quad$ The Breviary of Esthetic}

the immediate consciousness of the artist when he produces, or of the man of taste when he contemplates; it must widen and elevate itself to what is called explanation. And since in the world of history (which is, indeed, the only world) negative or privative facts do not exist, what seems to taste to be ugly and repugnant, because not artistic, will be neither ugly nor repugnant to historical consideration, because it knows that what is not artistic yet is something else, and has its right to existence as truly as it has existed. The virtuous Catholic allegory composed by Tasso for his "Gerusalemme" is not artistic, nor the patriotic declamation of Niccolini and Guerrazzi, nor the subtleties and conceits which Petrarch introduced into his poems; but Tasso's allegory is one of the manifestations of the work of the Catholic counter-reform in the Latin countries; the declamations of Niccolini and of Guerrazzi were violent attempts to rouse the souls of Italians against the priest and the stranger, representing adhesion to the manner of that arousing ; the subtleties and conceits of Petrarch, the cult of traditional troubadour elegance, revived and enriched in the new Italian civilisation; that is to say, they are all practical facts, very significant historically and worthy of respect. We can well continue to talk of the beautiful and of the ugly, in the field of historical criticism, through vivacity of language, or in order to chime with current parlance; provided that we shew at the same time, or hint, or let be understood, or at least do not exclude, the positive content, both of that beautiful and of that ugly, which will never be so radically condemned in its ugliness as when it is fully justified and understood, because in this case it will be removed in the most radical manner from the sphere proper to art.

For this reason, criticism of art, when truly æsthetic or historical, becomes at the same time amplified into a criti- 
cism of life, since it is not possible to judge - that is, to characterise-works of art without at the same time judging and characterising the works of the whole life: as we observe with the truly great critics, and above all with De Sanctis, in his "History of Italian Literature" and in his "Critical Essays," who is as profound a critic of art as of philosophy, morality, and politics; he is profound in the one because profound in the other, and inversely: the strength of his pure xsthetic consideration of art is the strength of his pure moral consideration of morality. Because the forms of the spirit, of which criticism avails itself as categories of judgment, although ideally distinguishable in unity, are not materially separable from one another and from unity, under penalty of seeing them vanish before us. We cannot, therefore, speak of a distinction of art from other criticism, save in an empirical manner, to indicate that the attention of the speaker or writer is directed to one rather than to another part of his indivisible argument. And the distinction is also empirical (I have hitherto preserved this here, in order to proceed with didactic clearness) between criticism and history of art: a distinction which has been specially determined by the fact that a polemical element prevails in the study of contemporary art and literature, which causes it to be more readily called "criticism," while in that of the art and literature of a more remote period prevails the narra. tive tone, and therefore it is more readily termed "history." In reality, true and complete criticism is the serene historical narration of what has happened; and history is the only true criticism that can be exercised upon the doings of humanity, which cannot be not-facts, since they have happened, and are not to be dominated by the spirit otherwise than by understanding them. And since the criticism of art has shewn itself inseparable from other criticism, so the history of art 


\section{The Breviary of Esthetic}

can be separated from the complete history of human civilisation only for reasons of a literary nature, among which it certainly follows its own law, which is art, but from which it receives the historical movement, which belongs to the spirit as a whole, never to one form of the spirit separated from the others.

Benedetto Croce. 


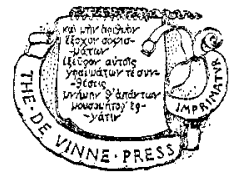


